\title{
Storm phosphorus concentrations and fluxes in artificially drained landscapes of the US Midwest
}

\author{
Philippe Vidon $^{1^{*}}$, Hilary Hubbard ${ }^{2}$, Pilar Cuadra $^{2}$, Matthew Hennessy ${ }^{2}$ \\ ${ }^{1}$ Department of Forest and Natural Resources Management, The State University of New York College of Environmental Science \\ and Forestry, SUNY-ESF, Syracuse, USA; ${ }^{*}$ Corresponding Author: pgvidon@esf.edu \\ ${ }^{2}$ Department of Earth Sciences, Indiana University-Purdue University, IUPUI, Indianapolis, USA
}

Received 21 March 2012; revised 24 April 2012; accepted 10 May 2012

\section{ABSTRACT}

This study investigates phosphorus $(P)$ concentrations and fluxes in tile drains, overland flow, and streamflow at a high temporal resolution during 7 spring storms in an agricultural watershed in Indiana, USA. Research goals include a better understanding of 1 ) how bulk precipitation and antecedent moisture conditions affect $P$ concentrations and fluxes at the watershed scale; 2) how $P$ concentrations and fluxes measured in tile drains translate to the whole watershed scale; 3 ) whether P losses to the stream are significantly affected by overland flow. Results indicate that bulk precipitation and antecedent moisture conditions are not good predictors of SRP or TP losses (either concentration or flux) to the stream. However, along with previously published storm data in this watershed, results indicate a threshold-based behaveior whereby SRP and TP fluxes significantly increase with precipitation when bulk precipitation exceeds $4 \mathrm{~cm}$. Although total SRP and TP fluxes are very much driven by flow, SRP and TP fluxes are somewhat limited by the amount of $P$ available for leaching for most storms. On average, SRP fluxes in tile drains are $13 \%$ greater than in the stream, and stream SRP fluxes account for $45 \%$ of TP fluxes at the watershed scale. Our results indicate that when $P$ is the primary concern, best management practices aimed at reducing $P$ losses via tile drains are likely to have the most effect on $P$ exports at the watershed scale.

Keywords: Total Phosphorus; Dissolved Reactive Phosphorus; Scale; Precipitation; Sub-Surface Drainage; Export Rate

\section{INTRODUCTION}

Continuous increases in human population and associated activities (use of fertilizers, waste water treatment plants) in the United States in the last 50 years have led to a significant increase in phosphorous (P) release to surface water in many regions [1]. This addition of phosphorus to freshwater systems has been tied to excessive algae growth and taste and odor problems in many freshwater environments, and to overall ecosystem degradation in estuaries and coastal areas [1-3]. Within this context, the US Midwest has been identified as a major contributor to P losses in the Mississippi River Basin (MRB) [1]. There has therefore been much interest in the past few decades in better understanding the processes regulating $\mathrm{P}$ losses to streams in artificially drained landscapes of the US Midwest where subsurface drainage is common, and where large inputs of $\mathrm{P}$ to streams have been reported [1,4].

In Illinois, Royer et al. (2006) showed that most P exports to streams occur during high flow periods ( $>80 \%$ of annual $\mathrm{P}$ export occurred during extreme discharge events) and that $\mathrm{P}$ losses to streams often exhibit a strong seasonal pattern with most $\mathrm{P}$ export occurring between mid-January and June [4]. Consistently with that finding, Vidon et al. (2008) showed that stream total phosphorus (TP) concentrations in excess of $0.125 \mathrm{mg} / \mathrm{L}$ occurred more often (58\% - $79 \%$ of the time) during high flow periods (i.e. winter and spring) than in the summer (33\% - 64\%) for a series of agricultural streams in Indiana [5]. Understanding the processes regulating $\mathrm{P}$ losses to streams in late winter-early spring during high flow events is therefore of primary importance in order to reduce $\mathrm{P}$ losses to streams without negatively affecting crop yield in artificially drained landscapes of the US Midwest. In that regard, a better estimate of total phosphorus (TP) and soluble reactive phosphorus (SRP) fluxes to stream is extremely important as fluxes, more so than concentration, ultimately control $\mathrm{P}$ loadings to the Mississippi 
River and the Gulf of Mexico.

However, in spite of the recognized importance of high flow periods in regulating $\mathrm{P}$ losses at the watershed scale, most studies reporting $P$ fluxes do so on a seasonal or annual basis [4,6,7]. Studies that report $\mathrm{P}$ losses on a storm event basis, often focus on tile drains [8] or take place in other regions such as Denmark $[9,10]$ or Ontario, Canada [11,12]. For instance, Vidon \& Cuadra (2011) report SRP and TP fluxes for two tile drains in a tile drained watershed in central Indiana, and showed that these fluxes were extremely variable from storm to storm, with SRP and TP fluxes ranging from 0.1 - $18.3 \mathrm{~g} / \mathrm{ha} / \mathrm{storm}$ for SRP, and 1 - $86.4 \mathrm{~g} / \mathrm{ha} / \mathrm{storm}$ for TP [8]. In Denmark, Kronvang et al. (1997) report particulate phosphorus (TP-SRP) losses in tiledrains for 17 storms over a two-year period varying approximately between 1 and $23 \mathrm{~g} \mathrm{P} / \mathrm{ha} / \mathrm{storm}$ [9]. Many studies also report P losses at the watershed scale and show that stream bank erosion and/or overland flow often significantly contribute to P losses, but these studies rarely integrate plot scale measurements (tile drains) with watershed scale measurements (stream) during storms [13-16]. This lack of integration between $\mathrm{P}$ exports in tile drains and associated $\mathrm{P}$ exports in streams strongly limits our ability to scale the results obtained at the plot scale (tile drain) to the entire watershed (stream). It also limits our ability to determine to what extent $\mathrm{P}$ losses in the stream mirror $\mathrm{P}$ losses in tile drains, and to establish the relative importance of tile drain flow and overland flow in regulating $\mathrm{P}$ losses a the watershed scale. Such information is critically needed to inform eitherthe use of best management practices (BMP) known to affect the relative importance of overland flow vs. infiltration (and therefore tile drain flow) (e.g. cover crop, tile drain spacing, tillage practices, etc.), or the implementation of BMPs designed, at least in part, to reduce direct overland flow contributions to the stream (e.g. stream/riparian zone restoration, riparian zone management).

Finally, focusing efforts during storm events is of primary importance because most $\mathrm{P}$ losses to streams occur during high flow events [4], and most climate change models predict not only an increase in temperature in the coming years, but also an increase in the intensity and frequency of storm events in many areas around the globe, including the US Midwest [17-19]. Understanding the relationship between precipitation characteristics (e.g. bulk precipitation), antecedent moisture conditions, and $\mathrm{P}$ concentrations and fluxes in the US Midwest is therefore of primary importance to determine how future changes in precipitation patterns might affect $\mathrm{P}$ losses to streams in the MRB. From a regulatory stand-point, better estimates of $\mathrm{P}$ fluxes on a daily or sub-daily basis are also needed to help States develop better total maximum daily load estimates for nutrient-impaired streams and rivers [4].

Key research questions addressed in this study include: 1) how do bulk precipitation and antecedent moisture conditions affect $\mathrm{P}$ concentrations and fluxes at the watershed scale? 2) how do $\mathrm{P}$ concentrations and fluxes measured in tile drains translate at the whole watershed scale? and 3) are P losses to the stream significantly affected by overland flow (when it occurs), and what is the relative importance of SRP in TP losses at the watershed scale? The implications of our results for watershed management are also discussed. In order to achieve these objectives, we measured bulk precipitation, antecedent moisture conditions, and SRP concentrations and fluxes for seven storms in two tile drains, the stream, overland flow (if any), and precipitation in Leary Weber Ditch, an artificially drained watershed representative of agroecosystems of the US Midwest. We also measured TP concentrationsin the stream for four selected storms to establish the relative importance of SRP in TP for a variety of hydrological conditions.

\section{MATERIAL AND METHODS}

\subsection{Site Description}

Leary Weber Ditch (LWD) $\left(7.2 \mathrm{~km}^{2}\right)$ is located in the larger Sugar Creek watershed, approximately $20 \mathrm{~km}$ east of Indianapolis, Indiana (Figure 1). Climate at the site is classified as temperate continental and humid. The average annual temperature for central Indiana is $11.7^{\circ} \mathrm{C}$ with an average January temperature of $-3.0^{\circ} \mathrm{C}$ and an average July temperature of $23.7^{\circ} \mathrm{C}$. The long-term average annual precipitation (1971-2000) is $100 \mathrm{~cm}$ [20]. Soils in the watershed are dominated by well-buffered poorly drained loams or silt loams, and typically belong to the Crosby-Brookston association. Crosby-Brookston soils are generally deep, very poorly drained to somewhat poorly drained with a silty clay loam texture in the first $30 \mathrm{~cm}$ of the soil profile. Soils in LWD are suited for row crop agriculture such as corn and soybean but require artificial drainage to lower the water table, removing ponded water, adding nutrients and ensuring good soil tilth. Conventional tillage and a corn/soybean rotation has been implemented consistently for the last 20 years in LWD. Each year, approximately $50 \%$ of the watershed is planted with corn, and the remaining portion is planted with soybean. Soybean is generally planted early May, and glyphosate applied mid-May. Phosphorus application on soybean generally averages $112 \mathrm{~kg} \cdot \mathrm{ha}^{-1} \cdot \mathrm{yr}^{-1}$. For corn, fertilizer as anhydrous ammonia is generally applied at a rate of $180 \mathrm{~kg} \cdot \mathrm{N} \cdot \mathrm{ha}^{-1} \cdot \mathrm{yr}^{-1}$ and herbicides atrazine and acetochlor are generally applied mid-May. Potash $\left(\mathrm{K}_{2} \mathrm{O}\right)$ is applied post-harvest on soybean fields at a rate of approximately $220 \mathrm{~kg} \cdot \mathrm{ha}^{-1}$. LWD (87\% row crop, 6\% pasture, $7 \%$ non-agricultural land use) is representative of 
many watersheds in the US Midwest where poorly drained soils dominate, and where artificial drainage is commonly used to lower the water table [21].

\subsection{Field and Laboratory Measurements}

A total of 7 storms were monitored between February and June in 2009 and 2010. Bulk precipitation for the storms studied was measured using a network of 7 rain gages distributed throughout the watershed. The two tile-drains monitored for this study (TD1 and TD2) are located in the headwaters of the watershed (Figure 1). Each tile-drain is $20.3 \mathrm{~cm}$ ID and located approximately $120 \mathrm{~cm}$ below the ground surface. TD1 extends $660 \mathrm{~m}$ from the stream and drains an area approximately 8.1 ha in size. TD2 extends $710 \mathrm{~m}$ from the stream and drains an area approximately 6.1 ha in size. Each tile drain was equipped with a Doppler velocity meter (ISCO 2150) for continuous discharge measurements, and a In-Situ LTC probe (level-temperature-conductivity). Whenever possible (i.e. when the stream water level was below the tile drain), discharge was also measured by hand using the bucket method to validate discharge measurements obtained with the Doppler velocity meters. No significant differences between manual and automated discharge measurments were found. The occurrence of overland flow was measured using a H-flume inserted into the ground, equipped with a In-Situ LT (level-temperatue) logger (In-Situ Inc.). Stream stage at the outlet of the watershed was measured using an In-Situ LTC probe (In-Situ Inc.). Discharge was measured biweekly using a handheld Doppler velocity meter (Sontek) so a rating curve could be established. A total of 8 riparian zone wells were also installed between the field edge and the stream to capture antecedent water table depth at the field edge before each storm, as well as riparian groundwater quality.

Water samples for soluble reactive phosphorus (SRP) analysis were collected in tile drains 1 and 2 (TD1 ans TD2), in overland flow (if any), and in the stream using auto samplers (ISCO 6712). In the stream, water samples for total phosphorus analysis (TP) were collected for storms 1, 2, 4 and 6 only, to minimize project cost. In tile drains, the sample collection line from each ISCO sampler was located at least $1 \mathrm{~m}$ into the tile-drains, and Doppler velocity measurements confirmed that no flow reversals occurred in the tile-drains during the storms studied, therefore indicating that tile samples were not contaminated by stream water when the tiles were submerged during storms. Samplers used to collect water samples in the stream and the two tile drains were triggered manually before the beginning of each storm, and generally set to collect water samples every 20 minutes during the rising limb of the hydrograph or the first 24 hours of the storm. Each 1L sample was a composite of 3

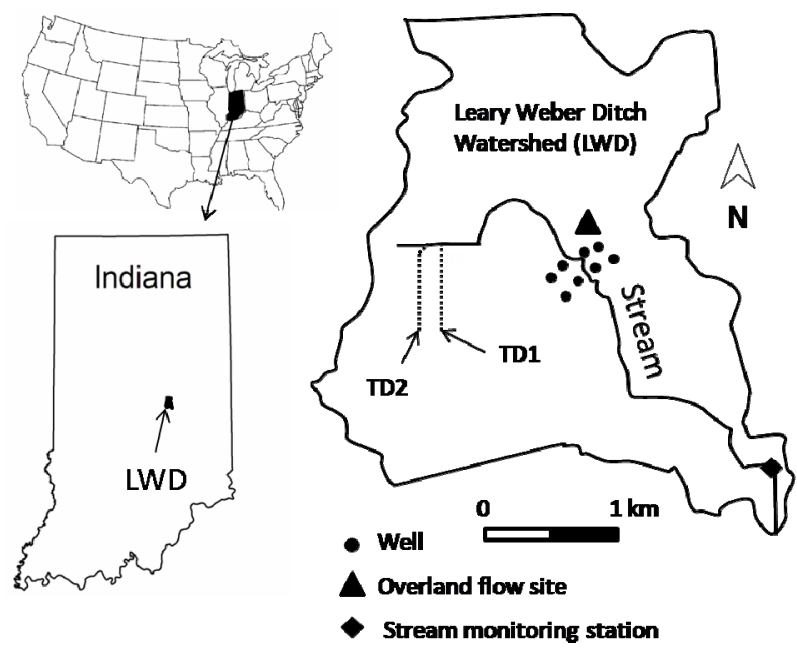

Figure 1. Experimental site location. TD1 and TD2 correspond to the two tile drains monitored for this study in 2009 and 2010.

samples taken 20 minutes apart ( 1 bottle per hour $=24$ hours). Sampling interval was extended to 2 hours (3 samples taken 40 minutes apart per bottle) on the falling limb of the hydrograph. Although all water samples collected on the rising limb of the hydrograph and around peak flow were analyzed, not all samples were necessarily analysed on the falling limb of each hydrograph to limit cost. Additional water samples were also collected in riparian groundwater wells (immediately before each storm) and in rain gages (immediately after each storm) to measure riparian and precipitation water chemitry for each of the storms studied.

Water samples were never left more than 24 hours in the field and were immediately filtered using GF/F Whatman $0.7 \mu \mathrm{m}$ filter upon return to the laboratory (except TP samples). Triplicate analysis of $10 \%$ of all samples and analysis of check standards every 10 samples were performed to assess measurement error, and check for the accuracy and precision of measurement techniques. The standard error on reported solute values was typically less than $10 \%$ for all solutes. Both SRP and TP (after a persulfate digestion) concentrations were determined colorimetrically using standard methods [22] on a Konelab 20 Photometric Analyzer (EST Analytical).

\subsection{Hydrological Dataanalysis and Flux Calculations}

For this study, the start of each event was defined when a perceptible rise in discharge in the stream was observed. The end of the event was defined when flow in the stream returned to pre-event flow values or when a new event started, which ever occurred first. Seven and fourteen day antecedent discharges (7 dQ and $14 \mathrm{dQ}$, respectively) in the stream were calculated as the mean discharge during the 7 and 14 days preceeding each event. 
Solute fluxes in gram of $\mathrm{P}$ per storm were calculated for each storm by first multiplying the concentration of the sample for each sampling interval $(\mathrm{mg} / \mathrm{L})$ by the average discharge for that interval (L/s) and a unit conversion factor. Fluxes reported here in g/ha/storm were obtained by dividing the solute flux for each storm (g/storm) by the contributing area to each tile-drain $\left(\mathrm{m}^{2}\right)$ or the stream $\left(\mathrm{m}^{2}\right)$ and a unit conversion factor. Solute export yields ( $\mathrm{g} / \mathrm{ha} / \mathrm{hr}$ ) before each storm were calculated as the flux in the hour preceding the beginning of the storm. Solute export yields (g/ha/hr) during storms are calculated as the average hourly solute fluxes over the duration of the storm. Significant differences between groups were established using student t-tests. Significance was established at $\mathrm{p}<0.05$.

\section{RESULTS}

The 7 storms studied ranged from $1.02 \mathrm{~cm}$ to $4.45 \mathrm{~cm}$ in bulk precipitation (Figure 2), with maximum average daily stream flows varying between 290 - $480 \mathrm{~L} / \mathrm{s}$ for storms when overland flow occurred (storms 3, 5, and 6), and between 87 - $164 \mathrm{~L} / \mathrm{s}$ for storms without overland flow (storms 1, 2, 4 and 7). Mean tile flow during storms varied from $0.5 \mathrm{~L} / \mathrm{s}$ (storm 1, TD1) to approximately 13 L/s for storms 3 and 6 in TD2, with peak tile flow generally occurring with or immediately before the peak in stream flow (data not shown). Water table depth at the field edge in the hours preceding the beginning of each storm ranged from 127 - $167 \mathrm{~cm}$ below ground surface (BGS) for storms 1, 2, 4, and 7, and from $97-125 \mathrm{~cm}$
BGS for storms 3, 5 and 6. Antecedent flow conditions (i.e. 7 and 14 day antecedent flow) were highest for storms with higher maximum average daily flow and overland flow (i.e. storms 3, 5 and 6) than for other storms (Figure 2). Bulk precipitation amounts were however not consistently higher for storms 3, 5, and 6 (1.02 cm $<$ bulk precipitation $<4.45 \mathrm{~cm}$ ) than for storms $1,2,4$ and 7 $(2.03 \mathrm{~cm}<$ bulk precipitation $<2.67 \mathrm{~cm})$.

Soluble reactive phosphorus (SRP) concentrations immediately before and during storms 1 - 7 are presented in Table 1 for the stream, tile drains 1 and 2 (TD1 and TD2), precipitation and riparian zone groundwater. Overland flow (OLF) only occurred for storms 3, 5, and 6, so SRP concentrations in OLF are only reported for these storms. Before the storms, SRP concentrations were the most variable in riparian zone wells with SRP varying by one order of magnitude between storms 6 and 7 (0.01 $\mathrm{mg} / \mathrm{L})$, and storm 1 (0.15 mg/L). SRP concentration was high in the stream at baseflow before storm $1(0.30 \mathrm{mg} / \mathrm{L})$ but remained in the $0-0.02 \mathrm{mg} / \mathrm{L}$ range for all other storms. When TD1 and TD2 were flowing before the storms, SRP concentrations varied between $0.01-0.02$ $\mathrm{mg} / \mathrm{L}$. SRP concentrations in precipitation varied by one order of magnitude from storm to storm $(0.01-0.49$ $\mathrm{mg} / \mathrm{L})$.

During storms, mean SRP concentrations in TD1 and TD2 varied between $0.01 \mathrm{mg} / \mathrm{L}$ storm 2$)$ and $0.04 \mathrm{mg} / \mathrm{L}$ (storm 3). In the stream, mean SRP concentrations (0.01 - $0.04 \mathrm{mg} / \mathrm{L}$ ) were generally 2 to 4 times higher than at baseflow. The only exception is for storm 1 , which started

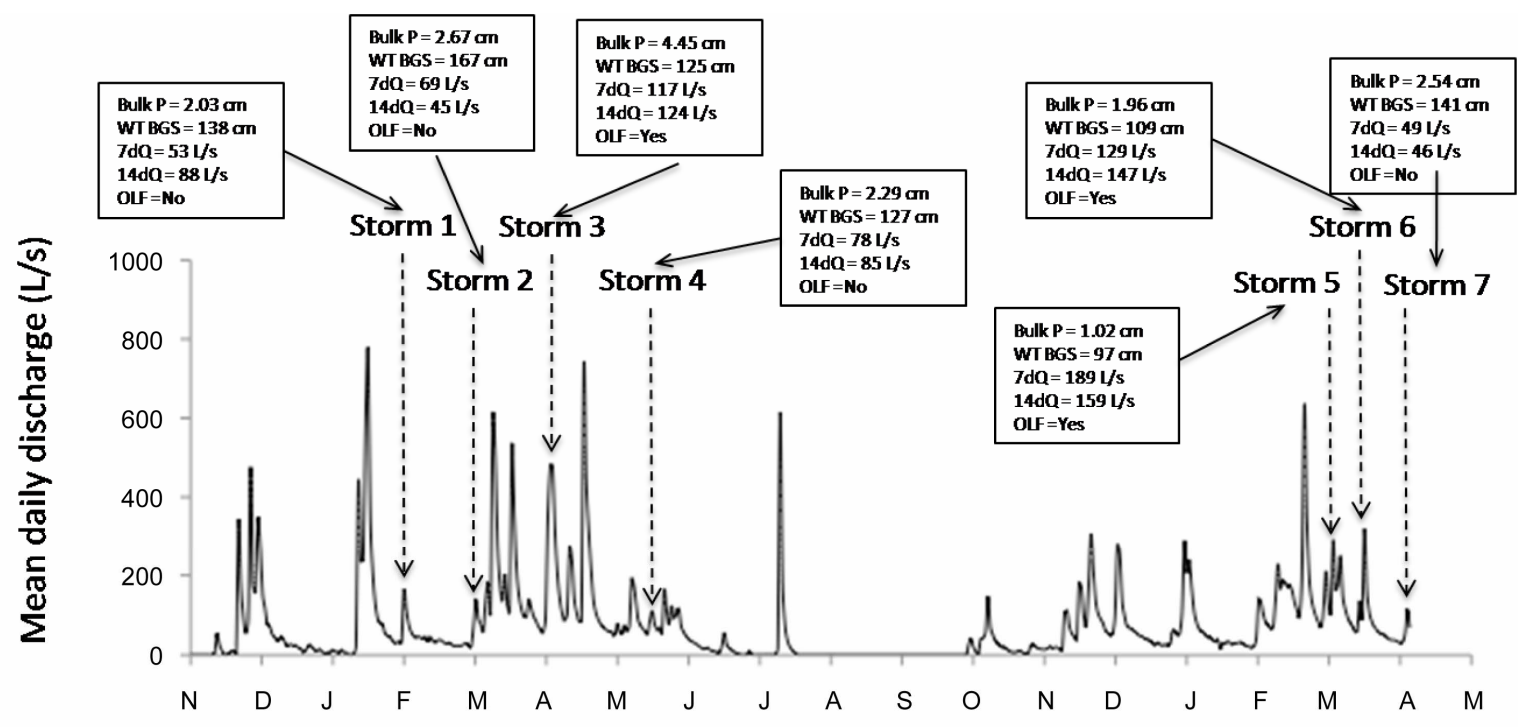

Figure 2. Mean daily discharge (L/s) in the stream at the outlet of the study watershed (Leary Weber Ditch) between November 2008 and May 2010. Storm 1 (February 26, 2009), storm 2 (April 1, 2009), storm 3 (April 29, 2009), storm 4 (June 11, 2009), storm 5 (March 29, 2010), storm 6 (April 8, 2010), and storm 7 (April 26, 2010) are the storms during this period for which water samples were collected in the watershed. Bulk precipitation amounts (Bulk P), antecedent water table depth below ground surface (WT BGS), 7-day antecedent discharge (7 dQ), 14-day antecedent discharge (14 $\mathrm{dQ}$ ), and the occurrence of overland flow (OLF) are also indicated for each storm. 
Table 1. Mean soluble reactive phosphorus (SRP) concentrations before storm 1 (February 26, 2009), storm 2 (April 1, 2009), storm 3 (April 29, 2009), storm 4 (June 11, 2009), storm 5 (March 29, 2010), storm 6 (April 8, 2010), and storm 7 (April 26, 2010) in the stream, tile drain 1 (TD1), tile drain 2 (TD2), and riparian groundwater. Mean SRP concentrations during storms 1 - 7 in precipitation, TD1, TD2, the stream, and overland flow (OLF) are also indicated. Values in parenthesis indicate one standard deviation (n/a = not available).

\begin{tabular}{|c|c|c|c|c|c|c|c|c|c|}
\hline \multirow{2}{*}{$\begin{array}{l}\text { Mean SRP } \\
(\mathrm{mg} / \mathrm{L})\end{array}$} & \multicolumn{4}{|c|}{ Pre-storm } & \multicolumn{5}{|c|}{ During storm } \\
\hline & Stream & TD1 & TD2 & $\mathrm{RZ}$ & Precip. & TD1 & TD2 & Stream & OLF \\
\hline Storm 1 & $0.30(0.19)$ & $\mathrm{n} / \mathrm{a}$ & $0.01(0.00)$ & $0.15(0.13)$ & $0.01(\mathrm{n} / \mathrm{a})$ & $\mathrm{n} / \mathrm{a}$ & $0.02(0.01)$ & $0.04(0.04)$ & - \\
\hline Storm 2 & $0.01(0.00)$ & $0.01(0.00)$ & $\mathrm{n} / \mathrm{a}$ & $0.02(0.01)$ & $0.13(\mathrm{n} / \mathrm{a})$ & $0.01(0.00)$ & $\mathrm{n} / \mathrm{a}$ & $0.02(0.00)$ & - \\
\hline Storm 3 & $0.01(0.00)$ & $0.02(0.01)$ & $0.01(0.00)$ & $0.02(0.01)$ & $0.49(\mathrm{n} / \mathrm{a})$ & $0.04(0.02)$ & $0.04(0.02)$ & $0.04(0.03)$ & $0.17(0.09)$ \\
\hline Storm 4 & $<\mathrm{BDL}$ & $0.01(0.00)$ & $0.01(0.00)$ & $0.03(0.02)$ & $0.01(\mathrm{n} / \mathrm{a})$ & $0.01(0.00)$ & $0.02(0.01)$ & $0.01(0.00)$ & - \\
\hline Storm 5 & $0.01(0.00)$ & $0.01(0.00)$ & $0.02(0.00)$ & $0.21(0.60)$ & $0.02(\mathrm{n} / \mathrm{a})$ & $0.02(0.00)$ & $0.02(0.01)$ & $0.02(0.01)$ & $0.58(1.70)$ \\
\hline Storm 6 & $<\mathrm{BDL}$ & $0.02(0.01)$ & No flow & $0.01(0.00)$ & $0.01(\mathrm{n} / \mathrm{a})$ & $0.03(0.01)$ & $0.04(0.01)$ & $0.02(0.03)$ & $0.26(0.02)$ \\
\hline Storm 7 & $0.02(0.02)$ & No flow & No flow & $0.01(0.00)$ & $0.06(\mathrm{n} / \mathrm{a})$ & $0.03(0.02)$ & $0.03(0.01)$ & $0.03(0.02)$ & - \\
\hline
\end{tabular}

on the tail end of a $770 \mathrm{~L} / \mathrm{s}$ mean daily discharge storm (Figure 2), and where high SRP concentrations before the storm were reported in the stream $(0.30 \mathrm{mg} / \mathrm{L}$, Table 1). SRP concentrations in overland flow were consistently one order of magnitude higher ( $0.17-0.58 \mathrm{mg} / \mathrm{L}$ ) than in the stream for storms 3, 5 and 6 (i.e. the 3 storms for which overland flow occurred). High temporal resolution SRP concentration patterns in the stream, TD1, and TD2 (Figure 3) revealed that SRP concentration patterns in TD1 and TD2 (when both were available) were generally similar to each other, but often different from SRP concentration patterns observed in the stream. For storms 1 and 2, stream SRP concentration showed a quick increase in concentration as discharge peaked. Conversely, a decrease in SRP concentration was observed in TD2 as discharge peaked for storm 1 (no data for TD1 for this storm). For storm 2, no clear changes in SRP concentration were observed in TD1 (no data for TD2 for this storm) as stream discharge peaked. For storm 3, both SRP in the stream and tile drains showed a sharp increase in concentration during the first peak in discharge. A smaller peak in SRP concentration was observed in the stream during the second peak in discharge. Grab samples in TD1 and TD2 during the second peak in discharge (no ISCO sampler data for this peak owing to equipment malfunction) are consistent with the occurrence of a second peak in SRP concentration in tile drains at this time. For storm 4, a steady increase in SRP concentrations in the stream and both tile drains was observed over the duration of the storm. For storm 5, although overall higher SRP concentrations were observed on the rising limb of the stream hydrograph in the stream (and to some extent in TD1 and TD2) than immediately before the beginning of this storm, individual SRP measurements remained highly variable from one sample to the next for this storm. For both storms 6 and 7, stream SRP showed a clear increase in concentration as a function of flow. However, in tile drains, SRP concentrations only slowly increased with flow (and remained high on the falling limb) for storm 6 , and did not show a consistent increase in concentration as a function of flow for storm 7.

TP concentrations measured in the stream for storms 1 , 2, 4 and 6 were $0.14 \mathrm{mg} / \mathrm{L}, 0.06 \mathrm{mg} / \mathrm{L}, 0.05 \mathrm{mg} / \mathrm{L}$, and $0.04 \mathrm{mg} / \mathrm{L}$, respectively (>100 samples) (Figure 4). For storms 1, 2, and 4, TP concentrations were significantly $(\mathrm{P}<0.05)$ higher than SRP concentrations. Although TP concentrations were also higher than SRP concentrations in the stream for storm 6 , they were not statistically significantly different $(P>0.05)$. TP concentrations generally showed a clear increase in concentration as a function of flow for all storms and peaked at the same time as SRP. The only exception is for storm 4 where SRP peaked after the peak in discharge, and where TP concentrations were extremely variable from one sample to the next.

SRP (all storms) and TP (stream only for storms 1, 2, 4 and 6) fluxes (g/ha/storm) and yields (g/ha/hr) are presented in Table 2. Baseflow SRP and TP yields are also reported for the stream. The average stream SRP flux for storms 1 - 7 was $2.01 \mathrm{~g} / \mathrm{ha} / \mathrm{storm}$, with a maximum flux of $8.76 \mathrm{~g} / \mathrm{ha} / \mathrm{storm}$ for storm 3 , and a minimum value of $0.39 \mathrm{~g} / \mathrm{ha} / \mathrm{storm}$ for storm 4 . In tile drains, average SRP fluxes were $2.37 \mathrm{~g} / \mathrm{ha} / \mathrm{storm}$ and $2.57 \mathrm{~g} / \mathrm{ha} / \mathrm{storm}$ in TD1 and TD2, respectively. Maximum SRP fluxes (8.20 $\mathrm{g} / \mathrm{ha} / \mathrm{storm}$ in TD1; $6.94 \mathrm{~g} / \mathrm{ha} / \mathrm{storm}$ in TD2) were also observed for storm 3 in tile drains. Average TP fluxes for storms 1, 2, 4, and 6 were $1.98 \mathrm{~g} / \mathrm{ha} / \mathrm{storm}$, which is approximately twice as high as the average SRP flux for these four storms $(0.89 \mathrm{~g} / \mathrm{ha} / \mathrm{storm})$. Stream SRP yield was on average 8 times larger during storms, than immediately before the storm. The highest increase in SRP yield in the stream was observed for storm 3, where SRP yield increased form $<0.001 \mathrm{~g} / \mathrm{ha} / \mathrm{hr}$ immediately before the storm began to $0.128 \mathrm{~g} / \mathrm{ha} / \mathrm{hr}$ during the storm. Although the average SRP yields in TD1 and TD2 were 

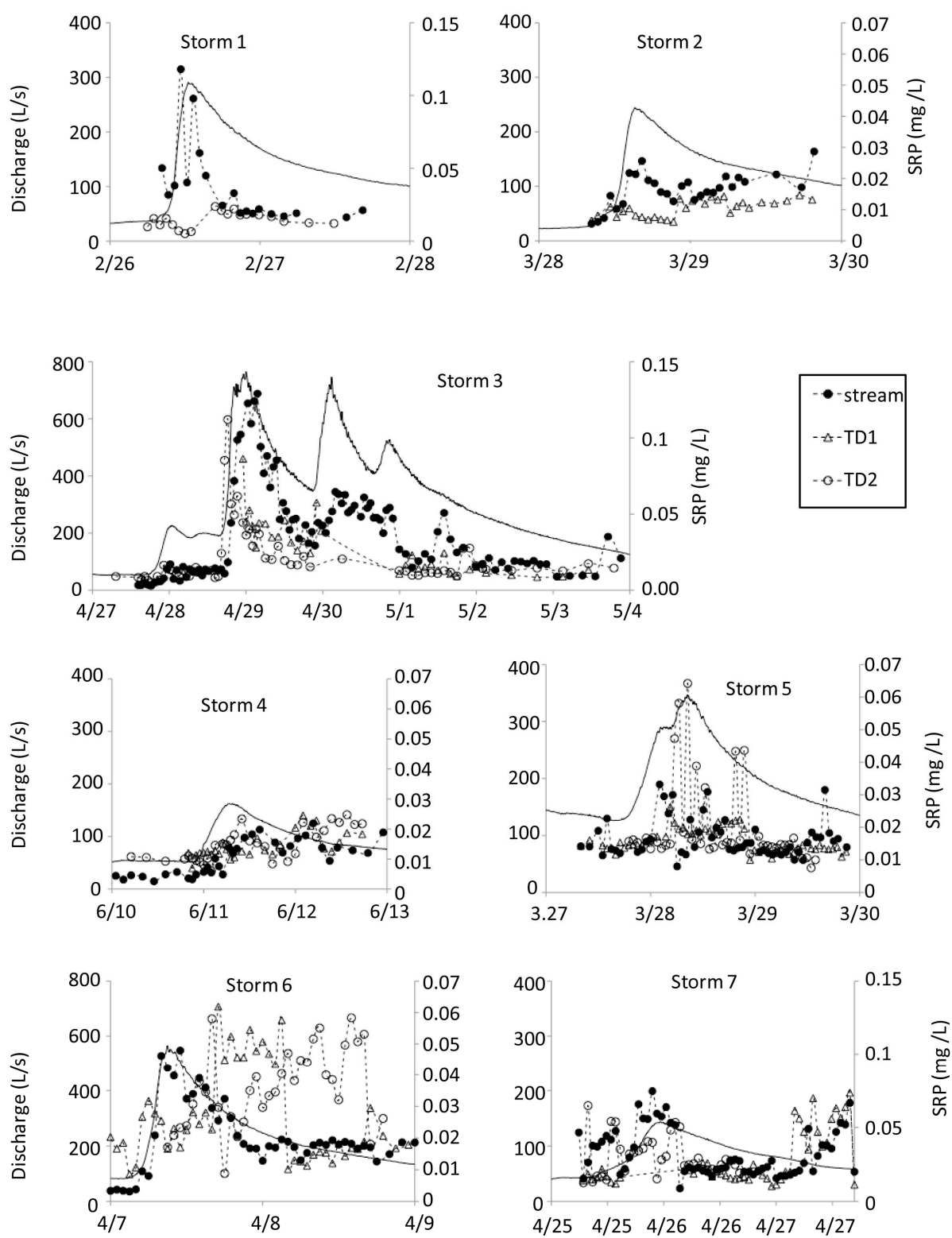

Figure 3. Stream discharge (L/s) (solid line), and soluble reactive phosphorus (SRP) concentrations in the stream (watershed outlet) and in tile drain 1 (TD1) and tile drain 2 (TD2) for storm1 (February 26, 2009), storm 2 (April 1, 2009), storm 3 (April 29, 2009), storm 4 (June 11, 2009), storm 5 (March 29, 2010), storm 6 (April 8, 2010), and storm 7 (April 26, 2010).

slightly lower than in the stream for storms 1 and 2, the average SRP yield in tile drains $(0.049 \mathrm{~g} / \mathrm{ha} / \mathrm{hr})$ for storms 1 - 6 (no flux data in tile drains for storms 7) was, on average, $23 \%$ higher than in the stream $(0.040$ $\mathrm{g} / \mathrm{ha} / \mathrm{hr}$ ). If fluxes (g/ha/storm) are compared simply on a storm basis (as opposed to an hourly basis), SRP fluxes in tile drains for storms $1-6(2.47 \mathrm{~g} / \mathrm{ha} / \mathrm{storm})$ are on average, $13 \%$ greater than in the stream $(2.19 \mathrm{~g} / \mathrm{ha} / \mathrm{storm})$. For storms 1, 2, 4, and 6 for which TP data are available, average TP yield for all 4 storms was 7.5 times higher during the storm $(0.054 \mathrm{~g} / \mathrm{ha} / \mathrm{hr})$ than immediately before $(0.007 \mathrm{~g} / \mathrm{ha} / \mathrm{hr})$.
Double mass curves (cumulated SRP or TP flux vs. cumulated discharge) indicate changes in the export rate of SRP or TP over the duration of a storm as a function of flow (Figure 5). For storm 3, the export rate of SRP over time (indicated by the slope of the double mass curve) varies over the course of the event, with a sharp increase in export rate at the beginning of the event (first $8 \mathrm{~mm}$ of discharge), followed by a steady export rate (linear curve) for the remaining of the event. A similar pattern was observed for storms 1 and 7, and to a lesser degree for storm 6. For storms 2, 4 and 5, the rate of SRP export was constant throughout the duration of these 
Table 2. Soluble reactive phosphorus (SRP) fluxes (g N/ha/storm) and yields (g/ha/hr) for storm 1 (February 26, 2009), storm 2 (April 1, 2009), storm 3 (April 29, 2009), storm 4 (June 11, 2009), storm 5 (March 29, 2010), storm 6 (April 8, 2010), and storm 7 (April 26, 2010) in tile drain 1 (TD1), tile drain 2 (TD2), and the stream (watershed outlet). Total phosphorus (TP) fluxes (g $\mathrm{N} / \mathrm{ha} / \mathrm{storm}$ ) and yields (g/ha/hr) for storms 1, 2, 4, and 6 in the stream. (Note: Fluxes in TD1 and TD2 for storm 7 were not calculated because discharge data in these tile drains were not available for this storm).

\begin{tabular}{|c|c|c|c|c|c|c|}
\hline & \multicolumn{4}{|c|}{ SRP Flux in $\mathrm{g} / \mathrm{ha} / \mathrm{storm}$} & \multicolumn{2}{|c|}{ TP Flux in g/ha/storm } \\
\hline & Stream (base flow) & Stream (storm flow) & TD1 & TD2 & Stream (base flow) & Stream (storm flow) \\
\hline Storm 1 & & 1.25 & $\mathrm{n} / \mathrm{a}$ & 0.58 & & 3.25 \\
\hline Storm 2 & & 0.50 & 0.32 & $\mathrm{n} / \mathrm{a}$ & & 1.72 \\
\hline Storm 3 & & 8.76 & 8.20 & 6.94 & & $\mathrm{n} / \mathrm{a}$ \\
\hline Storm 4 & & 0.39 & 0.39 & 0.47 & & 1.14 \\
\hline Storm 5 & & 0.84 & 0.93 & 2.13 & & $\mathrm{n} / \mathrm{a}$ \\
\hline Storm 6 & & 1.41 & 2.03 & 2.71 & & 1.82 \\
\hline \multirow[t]{3}{*}{ Storm 7} & & 0.90 & $\mathrm{n} / \mathrm{a}$ & $\mathrm{n} / \mathrm{a}$ & & $\mathrm{n} / \mathrm{a}$ \\
\hline & \multicolumn{4}{|c|}{ SRP Yield in $\mathrm{g} / \mathrm{ha} / \mathrm{hr}$} & \multicolumn{2}{|c|}{ TP Yield in $\mathrm{g} / \mathrm{ha} / \mathrm{hr}$} \\
\hline & Stream (base flow) & Stream (storm flow) & TD1 & TD2 & Stream (base flow) & Stream (storm flow) \\
\hline Storm 1 & 0.009 & 0.037 & $\mathrm{n} / \mathrm{a}$ & 0.018 & 0.010 & 0.096 \\
\hline Storm 2 & 0.001 & 0.014 & 0.008 & $\mathrm{n} / \mathrm{a}$ & 0.006 & 0.051 \\
\hline Storm 3 & $<0.001$ & 0.128 & 0.148 & 0.123 & $\mathrm{n} / \mathrm{a}$ & $\mathrm{n} / \mathrm{a}$ \\
\hline Storm 4 & 0.001 & 0.007 & 0.008 & 0.010 & 0.007 & 0.022 \\
\hline Storm 5 & 0.009 & 0.019 & 0.020 & 0.052 & $\mathrm{n} / \mathrm{a}$ & $\mathrm{n} / \mathrm{a}$ \\
\hline Storm 6 & 0.002 & 0.037 & 0.034 & 0.068 & 0.006 & 0.048 \\
\hline Storm 7 & 0.008 & 0.015 & $\mathrm{n} / \mathrm{a}$ & $\mathrm{n} / \mathrm{a}$ & $\mathrm{n} / \mathrm{a}$ & $\mathrm{n} / \mathrm{a}$ \\
\hline
\end{tabular}
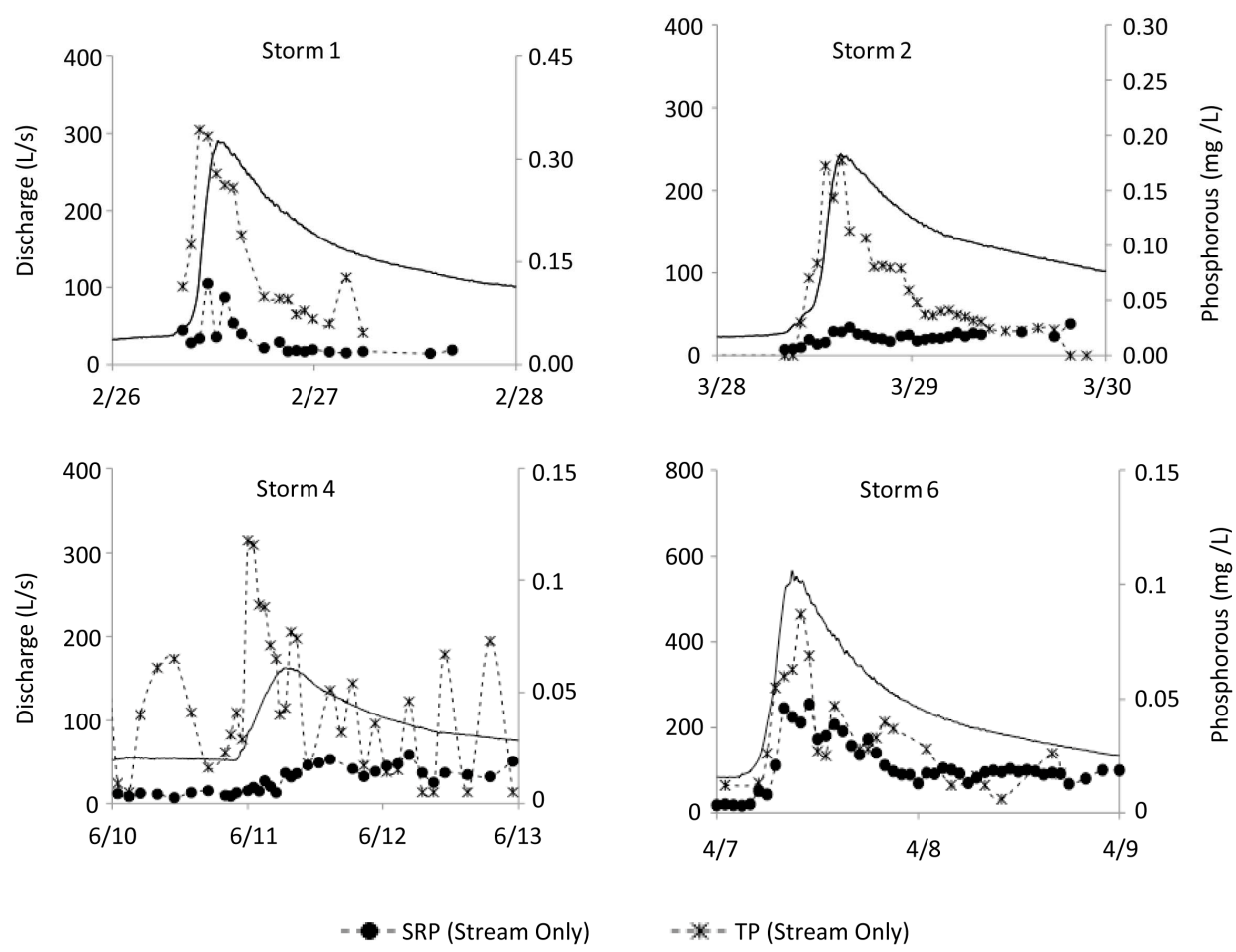

Figure 4. Stream discharge (L/s) (solid line), and soluble reactive phosphorus (SRP) and total phosphorus (TP) concentrations in the stream (watershed outlet) for storm 1 (February 26, 2009), storm 2 (April 1, 2009), storm 4 (June 11, 2009), and storm 6 (April 8, 2010). 

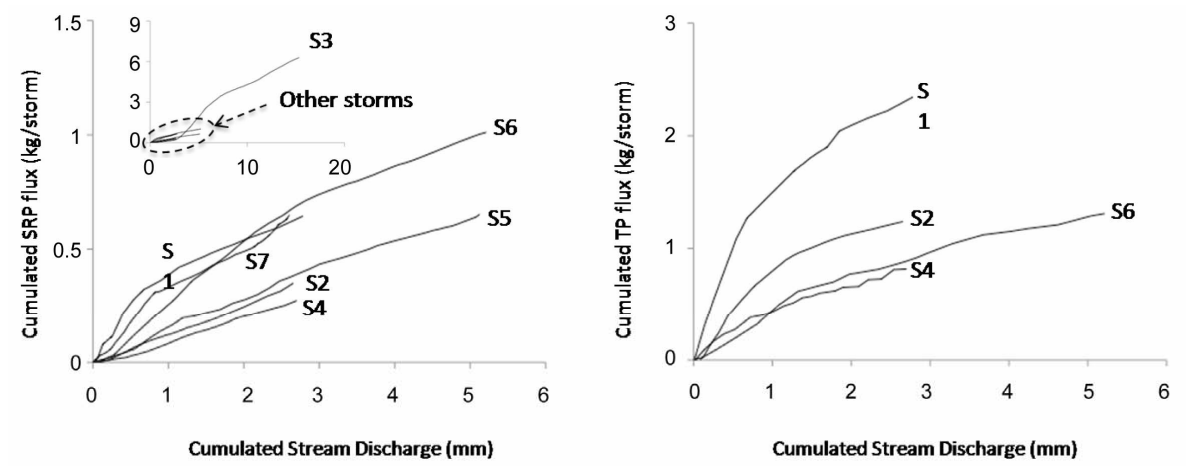

Figure 5. Double mass curves showing cumulated stream discharge $(\mathrm{mm})$ versus cumulated soluble reactive phosphorus flux (kg/storm) in the stream (watershed outlet) for storms 1 - 7 (left), and cumulated total phosphorus flux (kg/storm) in the stream for storms 1, 2, 4 and 6 (right).

storms. For TP, the export rateswere highly non linear for storms 1 and 2, with a progressive decrease of the rate of TP export over the duration of these storms. Although less pronounced than for storms 1 and 2, the export rates of TP over the duration of storms 4 and 6 also progresssively declined over the duration of these two storms.

\section{DISCUSSION}

In spite of gaps in the data set because of equipment malfunction (see results section for details), this data set is the first to present concentration and flux measurements for both SRP and TP in tile drains (in duplicate), overland flow, and stream flow across scale (plot scale to whole watershed scale) for a series of spring storms in the US Midwest. This offers a unique opportunity to empirically address key questions about the dynamics of $\mathrm{P}$ in artificially drained landscapes of the US Midwest at a time (late winter-spring) when most P losses to the Mississippi River Basin occur [4].

\subsection{How Do Bulk Precipitation and Antecedent Moisture Conditions Affect $P$ Concentrations and Fluxes at the Watershed Scale?}

Results indicate that high antecedent moisture conditions (storms 3, 5 and 6) are associated with the occurrence of overland flow and high mean daily discharge in the stream. The three highest mean SRP concentrations were however observed for storms 1,3 and 7 . When all the storms are combined, SRP concentrations are not significantly correlated $(\mathrm{P}>0.05)$ to bulk precipitation, or any of the measures of antecedent moisture conditions used in this study (i.e. water depth before the storm, 7 and 14 day antecedent flow conditions). High SRP concentrations (storms 1, 3, 7) in the stream are also not consistently associated with storms with overland flow (storms 3, 5 and 6) or significantly correlated (P > 0.05) to SRP concentrations in the stream at baseflow immediately before the storm. Similarly, mean storm TP concentrations measured for storms 1, 2, 4 and 6 are not significantly correlated $(\mathrm{P}>0.05)$ to hydrological conditions. This suggests that bulk precipitation and antecedent moisture conditions are likely not strong controls on SRP (or TP) concentrations in the stream in spring. Similarly, SRP concentration in tile drains are not significantly correlated to hydrological conditions.

In term of fluxes, the highest SRP flux is associated, in both tile drains and the stream, with the storm with the highest antecedent moisture conditions and highest bulk precipitation amount (storm 3) (Figure 2). Statistically speaking, SRP fluxes in the stream are significantly correlated to bulk precipitation ( $\mathrm{r}=0.83, \mathrm{P}<0.05$ ), but when storm 3 is removed, the correlation disappears $(\mathrm{r}=$ $0.30, \mathrm{P}>0.05$ ). A similar pattern is observed in tile drains. This suggests the existence of a threshold below which SRP fluxes are not influenced by bulk precipitation. Non-linear behavior in tile drains in terms of P export has been previously reported in this watershed [8]. In that study, the authors stress the non linear behavior of tile drains, especially in term of SRP exports, with SRP fluxes between 1 to 3 order of magnitude higher for storms associated with more than $6 \mathrm{~cm}$ of bulk precipitation than for those with less than $3 \mathrm{~cm}$ of bulk precipitation. Figure 6 combines the SRP and TP fluxes (g/ha/storm) in the stream, TD1, and TD2 reported here for 2009 and 2010 (7 storms, Table 2), with those reported in Vidon \& Cuadra (2011) in TD1 and TD2 for a series of storms in 2008 (4 storms) [8]. Together, these results suggest the existence of a threshold around $4 \mathrm{~cm}$ of bulk precipitation below which SRP and TP fluxes are not correlated to bulk precipitation. Above this threshold, a significant increase in SRP and TP flux is observed as bulk precipitation increases. This stresses the non-linear behavior of the watershed in terms of P export, and the existence of a threshold above and below which hydrological response 

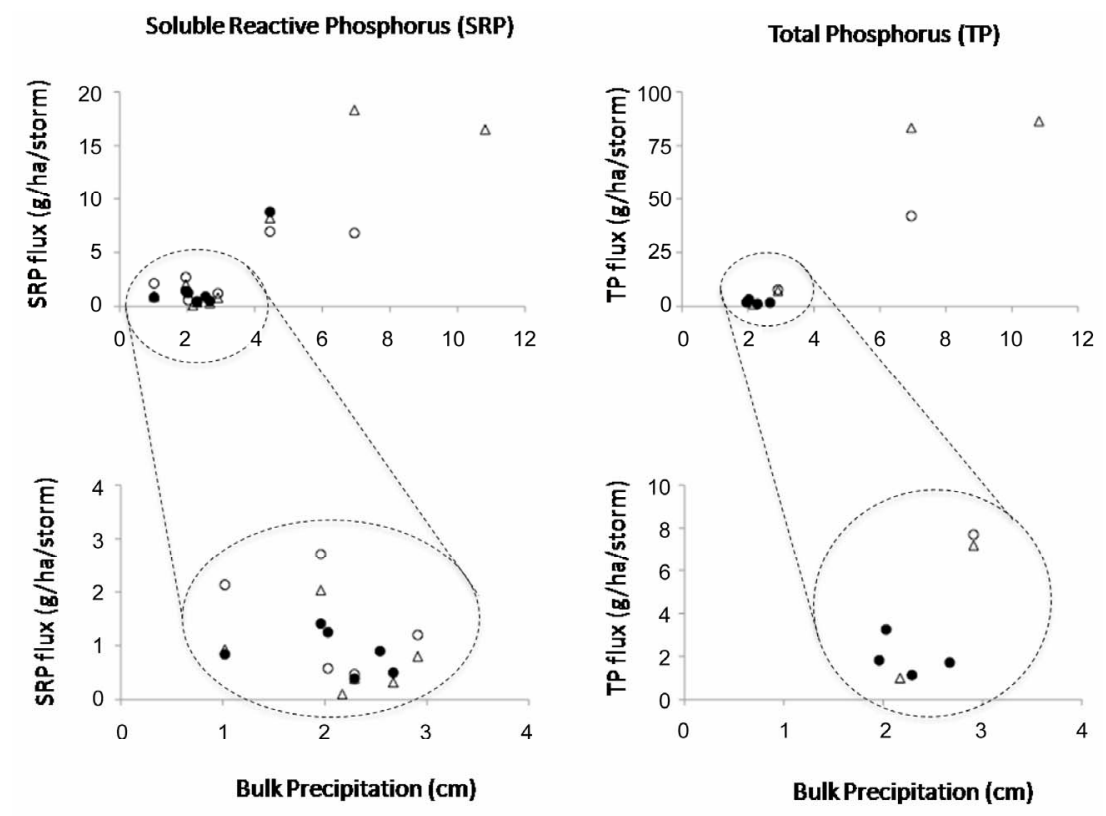

$$
\text { - Stream } \quad \triangle T D 1 \quad \text { OTD2 }
$$

Figure 6. Bulk precipitation amounts (cm) vs. soluble reactive phosphorus (SRP) fluxes (left) and total phosphorus fluxes (right) in kilogram per hectare in tile drain 1 (TD1), tile drain 2 (TD2), and the stream for storms 1 - 7 in 2009 and 2010 (this study), and for a series of four 2008 storms in TD1 and TD2 as reported in Vidon and Cuadra (2011).

drastically changes. One should therefore be cautious in generalizing relationships between $P$ fluxesand bulk precipitation or antecedent moisture conditions as those may change depending on individual storm characteristics.

The analysis of the double mass curves for SRP and TP (Figure 5) revealed that for storms 2, 4, and 5, the pool of SRP available for leaching was not limiting to SRP export. For other storms (i.e. storms 1, 3, 6 and 7) and for all storms for TP, data indicate a progressive exhaustion of the pool of SRP (and TP) available for leaching as these storms progressed. Indeed, a linear relationship between the cumulated discharge $(\mathrm{mm})$ and the cumulated solute flux $(\mathrm{kg})$ indicates that the rate of leaching remains constant over the duration of the storm. When a logarithmic shaped curve best fits the double mass curve (e.g. storm 1 or 2 for TP), this suggests that the leaching rate of the solute decreases towards the end of the storm. This indicates a progressive exhaustion of the solute pool available for leaching over the duration of the storm. Our results therefore suggest that for 4 out of 7 storms for SRP, and for 4 out of 4 storms for TP, SRP and TP pools are limiting to SRP and TP exports.

\subsection{How Do $P$ Concentrations and Fluxes Measured in Tile Drains Translate at the Whole Watershed Scale?}

Results indicate no consistent differences between mean SRP concentrations between TD1 and TD2, but also, and more importantly, no significant differences in mean SRP concentrations between the tile drains (TD1 and TD2) and the stream (Table 1). However, the timing of SRP concentration changes as a function of flow are not necessarily similar between tile drains and the stream (Figure 3). This suggests that although SRP concentration patterns as a function of flow may vary, tile drain data could potentially be used in heavily tile-drained watersheds of the US Midwest to estimate mean stream SRP concentrations when needed.

When SRP fluxes in the stream $(2.19 \mathrm{~g} / \mathrm{ha} / \mathrm{storm})$ are compared with those reported in TD1 (2.37 g/ha/storm) and TD2 (2.57 g/ha/storm) for storms 1 - 6, fluxes in tile drains are approximately $13 \%$ higher than in the stream. SRP yields (Table 2) are 23\% higher in tile drains than in the stream. This difference between fluxes (on a storm basis) and yields (on a hourly basis) stems from the flashier behavior of tile drains relative to the stream. However, regardless of whether yields or fluxes are used for comparison, $\mathrm{P}$ exports in tile drains remain higher (either on a per storm or hourly basis) than in the stream. Because $100 \%$ of the contributing area to each tile drain is agricultural (corn/soybean), it is likely that differences in land use contribute to the larger export rate of SRP in tile drains than in the stream at the whole watershed scale (87\% row crop, $6 \%$ pasture, $7 \%$ other (road + residen- 
tial)). Further, the mean flow path length is by definition shorter at the field scale (tile drain) than at the whole watershed scale. This difference in drainage intensity as a function of scale also likely contributes to the differences observed between SRP fluxes in tile drains and the stream.

Considering that most studies reporting SRP and/or TP fluxes at the watershed scale generally focus on either tile drains [8,9] or stream [4] but rarely both, it may be tempting for watershed managers trying to identify general patterns of $\mathrm{P}$ exports based on published work to use $P$ flux information obtained in tile drains to estimate $P$ fluxes at the watershed scale or vice-versa. Our data however suggest that higher fluxes (per hectare) will occur in tile drains (at the plot scale) than in the stream (at the watershed scale). Although we do not suggest that SRP fluxes in tile drains should be assumed to be consistently $13 \%$ higher than in the stream, we believe that in the absence of simultaneous flux estimates in tile drains and stream flow, one should apply a correction factor to available flux data to compensate for the overall difference in SRP fluxes observed between the stream and tile drains. We however believe that more studies are needed to better constrain the variables affecting the relationship between $\mathrm{P}$ fluxes in tile drains and $\mathrm{P}$ fluxes at the whole watershed scale. For instance, differences in land use between watersheds are likely to affect this ratio of $13 \%$ between SRP fluxes in tile drains and in the stream. Difference in tile drain diameter and spacing from one watershed to the next will also affect the drainage efficiency at the plot scale, and therefore the relationship between SRP fluxes in tile drains and in the stream at the whole watershed scale. Finally, this ratio was established based on 7 storms, in late winter-early spring, when the soil was bare or crops barely starting to emerge from the ground. It is likely that changes in vegetation development stage will affect this relationship over the course of an entire year. Consequently, although we recommend that a correction factor be applied when using tile drain flux data to establish whole watershed $\mathrm{P}$ losses (or vice-versa), we do not suggest that this correction factor be always assumed to be $13 \%$.

\subsection{To What Extent Does Overland Flow Affect $P$ Losses to the Stream, and What Is the Relative Importance of SRP in TP?-Implication of Results for Watershed Management}

Although SRP concentrations in overland flow are generally one order of magnitude higher than in tile drains for storms when overland flow occurs, this does not translate into higher stream SRP concentrations for these storms (Table 1). This suggests that at least in the watershed studied, SRP contributions to stream from overland flow are negligible from a mass balance standpoint, suggesting that efforts aiming at reducing SRP losses to streams in artificially drained landscapes should primarily focus on reducing SRP losses in tile drains. Previous work in the watershed indicates that overland flow (when it occurs) contributes, on average, $18 \%$ of stream flow for a series of storms ranging from $2.6 \mathrm{~cm}$ to $23.8 \mathrm{~cm}$ in bulk precipitation [23]. This work however also indicates that for storms associated with $<5 \mathrm{~cm}$ in precipitation (as in our study), overland flow generally only contributes to $<5 \%$ of stream flow [23]. Although 7 storms are monitored for SRP, our study only provides limited TP data (only 4 storms and for the stream only) but stream TP concentrations are not higher for storm 6 , during which overland flow occurred, than for storms 1 , 2 , and 4, for which no overland flow occurred. This is also consistent with overland flow not being a significant contributor to $\mathrm{P}$ losses (in terms of mass) to the stream, at least in spring for the range of storms studied $(1.02 \mathrm{~cm}<$ bulk precipitation $<4.45 \mathrm{~cm}$ ).

In terms of the relative concentration of SRP in TP, our results suggest that for the $>100$ samples collected in the stream for which both SRP and TP are available, SRP typically accounts for $39 \%$ of TP. When fluxes are compared, SRP fluxes represent $45 \%$ of TP fluxes. This is consistent with results reported by McDowell \& Wilcock (2004) in New Zealand, where stream SRP concentrations represented approximately $27 \%$ of TP concentrations in summer/fall and $35 \%$ of TP concentrations in winter/spring [15]. For three Illinois streams, Royer et al. (2006) reported that over a 12-month period, SRP fluxes represented $44 \%$ of TP fluxes [4]. In a series of storms in 2008, Vidon \& Cuadra (2011) indicatethat in TD1 and TD2, SRP fluxes typically accounted for $10 \%-22 \%$ of TP fluxes [8].

From a watershed management standpoint, these results indicate that efforts should be made to reduce both SRP and particulate phosphorus (PP) (PP = TP - SRP) losses to tile drains and the stream. Indeed, PP represents at least $60 \%$ of TP over multiple storms (in terms of concentration), and flux data indicate that PP losses are larger than SRP losses. However, SRP is more bioavailable than PP [24], and is therefore more likely to have a direct impact on ecosystem primary productivity (e.g. algae blooms); so from an ecosystem perspective, SRP is likely more important than PP. Our results also stress that although SRP concentrations are generally much higher in overland flow than in tile drains (Table 1); the occurrence of overland flow does not have any significant impact on $\mathrm{P}$ losses (concentration or flux) at the watershed scale for moderate size storms ( $<5 \mathrm{~cm}$ bulk precipitation). Consequently, although erosion control measures may have positive effects on water quality with respect to sediment losses [25] and pesticides losses [26]; when P is 
the primary concern, our results suggest that, at least for tile drain dominated systems in spring, best management practices with the potential to reduce $\mathrm{P}$ losses to stream via tile drains (wetlands intercepting tile drains, controlled drainage, tillage practices...) are likely to have more effects on $\mathrm{P}$ exports at the watershed scale than best management practices designed, at least in part, to reduce direct overland flow contributions to the stream (e.g. stream/riparian zone restoration, riparian zone management).

\section{CONCLUSION}

Overall, results suggest that bulk precipitation and antecedent moisture conditions are not good predictors of SRP or TP losses (either concentration or flux) to the stream, and that overland flow is not a significant contributor to $\mathrm{P}$ losses at the watershed scale for the storms studied ( $<5 \mathrm{~cm}$ bulk precipitation). Taken together with previous work in the watershed, our results suggest a threshold-based behavior for this watershed in terms of SRP and TP exports, whereby SRP and TP fluxes in either tile drains or the stream significantly increase with precipitation when bulk precipitation exceeds $4 \mathrm{~cm}$, but show no significant positive correlation with bulk precipitation below that threshold. If climate change predictions hold true and that the frequency of large precipitation events increases in the coming years in the US Midwest, we will likely see a significant increase in P losses to streams (assuming land use practices remain the same). However, for most storms, our data indicate that total SRP and TP losses are somewhat limited by the amount of $\mathrm{P}$ available for leaching (Figure 5). This suggests that although $\mathrm{P}$ losses in artificially drained landscapes of US Midwest are primarily driven by hydrology (high P flux during high flow conditions), further source reduction could potentially have a significant effect on overall $\mathrm{P}$ losses. Our results also indicate that SRP fluxesper unit drainage area are on average 13\% higher in tile drains than at the watershed scale on a storm basis (and 23\% higher on a hourly basis). Differences in land use and drainage intensity are logical explanation for these differences, but scaling ratios are not commonly reported in the literature. As discussed previously, these ratios (either storm or hourly ratios) should certainly be used with caution as they are likely to change with seasons, land use, and tile drain spacing/diameter, but when no empirical data linking plot scale flux estimates to whole watershed flux estimate are available, we propose that these ratios could be used as scaling ratios between tile drain flux observations and whole watershed flux estimates. It is important to note that over the course of an entire year, changes in crop development stage and antecedent moisture conditions play a critical role in regulating the hydrological response to precipitation of tile drained wa- tershedsin the US Midwest [27] or other regions such as Oregon [28,29], or Ontario [11,12]. Our results are therefore primarily applicable to the late winter/spring period in the US Midwest, when most P losses to streams on an annual basis occur [4].

\section{ACKNOWLEDGEMENTS}

The project described in this publication was supported by grant/ cooperative agreement number \# 08HQGR0052 to P. Vidon from the United States Geological Survey (USGS). Its contents are solely the responsibility of the authors and do not necessarily represent the official views of the USGS. Additional funding was also provided by an Indiana University-Purdue University, Indianapolis RSGF grant to P. Vidon and a Mirsky Fellowship to P.E. Cuadra. The authors would like to thank Lani Pascual, Vince Hernly and Bob E. Hall for help in the field and the laboratory, and Jeff Frey and Nancy Baker from the USGS Indianapolis Office for their help in the development phase of the project.

\section{REFERENCES}

[1] Alexander, R., Smith, R.S., Schwarz, G.E., Boyer, E.W., Nolan, J.V. and Brakebill, J.W. (2008) Differences in phosphorus and nitrogen delivery to the Gulf of Mexico from the Mississippi River Basin. Environmental Science and Technology, 42, 822-830. doi:10.1021/es0716103

[2] Carpenter, S.R., Caraco, N.F., Correll, D.L., Howarth, R.W., Sharpley, A.N. and Smith, V. (1998) Nonpoint pollution of surface waters with phosphorus and nitrogen. Ecological Applications, 8, 559-568. doi:10.1890/1051-0761(1998)008[0559:NPOSWW]2.0.C $\underline{\mathrm{O} ; 2}$

[3] David, M.B. and Gentry, L.E. (2000) Anthropogenic inputs of nitrogen and phosphorus and riverine export for Illinois, USA. Journal of Environmental Quality, 29, 494508. doi:10.2134/jeq2000.00472425002900020018x

[4] Royer, T.V., David, M.B. and Gentry, L.E. (2006) Timing of riverine export of nitrate and phosphorus from agricultural watersheds in Illinois: Implications for reducing nutrient loading to the Mississippi River. Environmental Science and Technology, 40, 4126-4131. doi:10.1021/es052573n

[5] Vidon, P., Tedesco, L.P., Pascual, D.L., Campbell, M.A., Casey, L.R., Wilson, J. and Gray, M. (2008) Seasonal changes in stream water quality along an agricultural/urban land-use gradient. Proceedings of the Indiana Academy of Sciences, 117, 107-123.

[6] Cooke, S.E. and Prepas, E.E. (1998) Stream phosphorus and nitrogen export from agricultural and forested watersheds on the Boreal Plain. Canadian Journal of Fisheries and Aquatic Sciences, 55, 2292-2299. doi:10.1139/f98-118

[7] Coulter, C.B., Kolka, R.K. and Thompson, J.A. (2004) Water quality in agricultural, urban and mixed land use watersheds. Journal of the American Water Resources Association, 40, 1593-1601. doi:10.1111/j.1752-1688.2004.tb01608.x 
[8] Vidon, P. and Cuadra, P.E. (2011) Phosphorus dynamics in tile-drain flow during storms in the US Midwest. Agricultural Water Management, 98, 532-540. doi:10.1016/j.agwat.2010.09.010

[9] Kronvang, B., Laubel, A. and Grant, R. (1997) Suspended sediment and particulate phosphorus transport and delivery pathways in an arable catchment, Gelbaek stream, Denmark. Hydrological Processes, 11, 627-642. doi:10.1002/(SICI)1099-1085(199705)11:6<627::AID-H YP481>3.0.CO;2-E

[10] Laubel, A., Jacobsen, O.H., Kronvang, B., Grant, R. and Andersen, H.E. (1999) Subsurface drainage loss of particles and phosphorus from field plot experiments and a tile-drained catchment. Journal of Environmental Quality, 28, 576-584. doi:10.2134/jeq1999.00472425002800020023x

[11] Macrae, M.L., English, M.C., Schiff, S.L. and Stone, M. (2007) Intra-annual variability in the contribution of tile drains to basin discharge and phosphorus export in a firstorder agricultural catchment. Agricultural Water Management, 92, 71-182. doi:10.1016/j.agwat.2007.05.015

[12] Macrae, M.L., English, M.C., Schiff, S.L. and Stone, M. (2010) Influence of antecedent hydrological conditions on patterns of hydrochemical export from a first-order agricultural watershed in Southern Ontario, Canada. Journal of Hydrology, 389, 101-110.

[13] Sharpley, A.N., Gburek, W.J., Folmer, G. and Pionke, H.B. (1999) Sources of phosphorus exported from an agricultural watershed in Pennsylvania. Agricultural Water Management, 41, 77-89. doi:10.1016/S0378-3774(99)00018-9

[14] Sekely, A.C., Mulla, D.J. and Bauer, D.W. (2002) Streambank slumping and its contribution to the phosphorus and suspended sediment loads to the Blue Earth River, Minnesota. Journal of Soil and Water Conservation, 57, 243250.

[15] McDowell, R.W. and Wilcock, R.J. (2004) Particulate phosphorus transport within streamflow of an agricultural catchment. Journal of Environmental Quality, 33, 21112121. doi:10.2134/jeq2004.2111

[16] Gentry, L.E., David, M.B., Royer, T.V., Mitchell, C.A. and Starks, K.M. (2007) Phosphorus transport pathways to streams in tile-drained agricultural watersheds. Journal of Environmental Quality, 36, 408-415. doi:10.2134/jeq2006.0098

[17] Karl, T.R. and Knight, R.W. (1998) Secular trends of precipitation amount, frequency, and intensity in the United States. Bulletin of the American Meteorological Society, 79, 231-241. doi:10.1175/1520-0477(1998)079<0231:STOPAF>2.0.C $\underline{\mathrm{O} ; 2}$
[18] Davis Todd, C.E., Harbor, J.M. and Tyner, B. (2006) Increasing magnitudes and frequencies of extreme precipitation events used for hydraulic analysis in the Midwest. Journal of Soil and Water Conservation, 61, 179-184.

[19] Milly, P.C.D., Dunne, K.A. and Vecchia, A.V. (2005) Global pattern of trends in streamflow and water availability in a changing climate. Nature, 438, 347-350. doi:10.1038/nature04312

[20] NOAA (2005) Climatological data, Indianapolis. National Oceanic and Atmospheric Administration, National Climatic Data Center.

http://www.crh.noaa.gov/ind/climatenormals.txt

[21] Lathrop, T.R. (2006) Environmental setting of the sugar creek and leary weber ditch basins, Indiana, 2002-04. U.S. Geological Survey Scientific Investigations Report, Reston.

[22] Clesceri, L.S., Greenberg, A.E. and Eaton, A.D. (1998) Standard methods for the examination of water and waste water. 20th Edition, American Public Health Association, Washington DC.

[23] Baker, N.T., Stone, W.W., Wilson, J.T. and Meyer, M.T. (2006) Occurrence and transport of agricultural chemicals in leary Weber ditch basin, Hancock County, IN, 2003-04. US Geological Survey Scientific Investigations Report, Reston.

[24] Ekholm, P. (1991) Bioavailability of phosphorus. In: Svendsen, L.M. and Kronvang, B., Eds, Phosphorus in the Nordic Countries. In Methods Bioavailability, and Measures, Nord, Vol. 47, Nordic Council of Ministers, Copenhagen, 109-120.

[25] McKergrow, L.A., Weaver, D.M., Prosser, I.P., Grayson, R.B. and Reed, A.E. (2003) Before and after riparian management: Sediment and nutrient exports from a small agricultural catchment, Western Australia. Journal of Hydrology, 270, 253-272.

[26] Shipitalo, M.J. and Owens, L.B. (2006) Tillage system, application rate, and extreme event effects on herbicide losses in surface runoff. Journal of Environmental Quality, 35, 2186-2194. doi:10.2134/jeq2005.0476

[27] Vidon, P., Hubbard, L.E. and Soyeux, E. (2009) Seasonal solute dynamics across land uses during storms in glaciated landscape of the US Midwest. Journal of Hydrology, 376, 34-47. doi:10.1016/j.jhydrol.2009.07.013

[28] Poor, C.J. and McDonnell, J.J. (2007) The effect of land use on stream nitrate dynamics. Journal of Hydrology, 332, 54-68. doi:10.1016/j.jhydrol.2006.06.022

[29] Wigington, P.J., Moser, T.J. and Lindeman, D.R. (2005) Stream network expansion: A riparian water quality factor. Hydrological Processes, 19, 1715-1721. doi:10.1002/hyp.5866 